\title{
Narratives on child and childhood in Greek city-states: an interview with Gillian Shepherd
}

\author{
Narrativas sobre a criança e a infância nas cidades-Estados \\ gregas: uma entrevista com Gillian Shepherd
}

\section{Gillian Shepherd*}

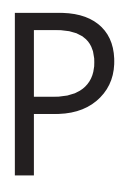

rof. Dr. Gillian Shepherd is Director of the Trendall Research Centre for Ancient Mediterranean Studies and Senior Lecturer in Classics and Ancient History at La Trobe University, Australia. Specializing in studies on Greek colonization in regions of Italy and Sicily, her research focuses on burial customs, ethnicity and identity in the Greek West, and children in antiquity. She is a co-editor of The Oxford Handbook of the Archaeology of Childhood (2018).

1. Luciane Munhoz de Omena: To start the discussion about the narratives about children and childhood in Antiquity, we think, above all, about the social appreciation of the child, as boys and girls mark childhood environments and objects. They become mnemonic agents because, in their daily lives, interspersed between games, study routine and domestic obligations, they become reminiscences and idealizations in the adult world. So considering the specificity of our area, we would like the teacher to reflect on the conceptual use of children, childhood and its applicability in Antiquity.

Gillian Shepherd: Philip Ariès' (1962, p. 134) famous assertion that there was no concept of childhood as a specific state separate to adulthood in premodern Europe has long been refuted, but his basic point - that childhood is a social construct as well as a physical state - remains important and one that must be kept in mind in any study of children and childhood in the past. Conceptions of what it is to be a child and of the state of childhood are, after all, notions which are formed retrospectively by adults, and can vary considerably over time, place and culture. Even the point at which an individual is

*Entrevista concedida a Luciane Munhoz de Omena em 21 de dezembro de 2020. 
considered to transition from child to adulthood is one such culturally defined watershed, since it does not always coincide with physical maturity.

In looking at the evidence from antiquity for children and childhood, it is clear that the ancient Greeks and Romans did view childhood as a separate and important phase of life. Our problem is, however, to tease out that evidence, avoiding facile assumptions derived from our own ideas of children and childhood, while at the same time making good use of such modern parallels that might be relevant - such as ethnographic evidence, or fundamental cognitive development. We can often find for antiquity much that appears familiar and to which we can readily relate - such as the scenes on Attic red-figure vases depicting a baby learning to walk or crawl, encouraged by two adults (parents?) and a toddler in a high-chair potty brandishing a rattle (NEILS; OAKLEY 2003 cat. 37; 41). Sometimes, however, closer examination can prove that the evidence may be more complicated that it appears at first sight, such as for the ancient Greek "dolls" with truncated legs discussed below. And there are common and accepted features of ancient society - such as girls marrying in their mid-teens, pederasty and child slavery - that clearly do not sit well with modern notions of childhood. Childhood in antiquity was as varied and complex as it is today, but was also subject to a different set of societal values and norms.

It is important not to forget a fact which should be obvious, but I suspect is often overlooked: simply, that children always made up a very significant proportion of the population in antiquity, probably a greater proportion than they do today. Estimates vary, but at least a third or more of a population must have been under 15 years of age at any one time, significantly higher than for the modern developed world (c. 19\%: PARKIN 2013, p. 41) and - again to state the obvious - the remainder of the population had also experienced childhood in some form. Today, in attempting to reconstruct what the societies of the ancient world must have been like, we tend to focus solely on adult interactions, priorities and agency, forgetting the very conspicuous presence of children in everyday life and indeed as you suggest their potential mnemonic value for adults recalling or even reliving in some way their own childhoods (cf Sophocles, Ajax, 552-59). This presence must have been most obvious in the domestic sphere, which is - ironically - also the place where we often find children hardest to "see": they are often more obvious in sanctuaries (e.g. types of votive offerings, imagery on votives) and most visible in cemeteries, as a result of abrupt terminations of childhood. Increasingly, though, we are finding new ways of "seeing" these very real, but invisible, children. 
2. If we turn our thoughts to the jokes such as marbles, dodge-ball, tongue-twister, hopscotch, hula hoop, rocking horse, board games, and so many others, which guided our social experience, we are curious about children's entertainment in the Western and Eastern Mediterranean. At the archaeological site of Conimbriga, province of Lusitania, excavations revealed artifacts related to educational and entertainment experiences, such as houses (simulacra domuum), miniature cars (plostella), dolls (pupae), toy soldiers (ducatus aut imperia), among others. Thus, playing house would prepare the child for social life, a kind of imitation. Therefore, the relationship between education and play is verified. In this sense, we would like you to take a stand on the following question: where the toys used by Greek children, considering their different temporalities, intended for paideia?

R: One of the problems we have - and it is not confined to Greek antiquity - is identifying toys in the archaeological record in the first place. This is not entirely surprising - after all, many would have been made of perishable materials, and even those that survive are not necessarily readily identifiable as toys as opposed to objects for some other purpose (compare in the modern world the common predilection of young children for finding the packaging more interesting than the actual toy). Sometimes the identification of a toy seems obvious: for example, spinning tops, or the toy rollers often depicted with small boys on vases, must have provided not only entertainment but also skills in dexterity. But in other situations the identification of a "toy" is not so clear and the context needs to be carefully considered. Two child graves in the Fusco Necropolis at Syracuse illustrate this problem well. One, a $7^{\text {th }}$ century burial in a small sarcophagus (Tomb 20: ORSI, 1895), contained a charming terracotta horse and cart set - it is difficult to interpret this as anything other than a toy, but at the same time it is worth underlining that such objects are very unusual in archaic-classical graves in Greek Sicily, and there is very little else that could so readily be identified as a toy. This is illustrated by the second child grave, which likewise contains an unusual object, this time in the form of a small Late Geometric bronze horse figurine (Museo Archeologico Regionale Paolo Orsi, Siracusa: Scavi Cavallari inv. 6279). It is of a Peloponnesian type generally found as a votive offering at sanctuaries in Greece. But what does it represent in this context? A toy horse with which the child actually played? The nostalgic gift of a grief-stricken parent who may have been amongst the first Greek migrants to Sicily? An assertion of parental status and disposable wealth, given the unusual and relatively costly nature of the item? The status of this particular child within the household unit? Or a combination of all of these things?

As at Conimbriga, small-scale versions of common objects present possible evidence for the use of playthings and play for education, training and socialisation. Another child 
grave in the Fusco Necropolis (Tomb 261: ORSI, 1895) contained a small, yet serviceable iron axe - although this particular object might be less convincing than some, given that it seems a highly unsuitable item to be put in the hands of a small child (even if we suppress $21^{\text {st }}$ century anxieties regarding child safety) and it had some wealth and prestige value as a metal object in a grave also. Other scaled-down versions of common objects provide more promising evidence for paideia through play, Miniature furniture exists, for example, which suggests play through an imagined household controlled by a child or children, even if there were no actual doll houses (NEILS; OAKLEY, 2003, p. 267). However, we need to be careful here also to consider the production and use of miniaturised objects for symbolic purposes, especially in ritual, that were not necessarily child-related (see for example PILZ, 2011).

Small scale vases provide an important case study in this regard. They appear in child graves throughout the Greek world, and such objects could certainly have been used in real life to learn domestic tasks through imitation of adult actions. Yet while such objects could have been toys, they were not necessarily always used as such. For example, in Greek Sicilian graves small Corinthian skyphoi appear in quantities in adult graves as well as child burials - and given their functional limitations, they appear more as objects suitable for deposition in the grave, and possibly acquired solely for that purpose, where the act and its symbolism were more important than the object's utilitarian function. A similar situation exists at Corinth, where small or miniature vases appear in child graves, but also in some adult graves. Small pots are also regularly found as votive offerings in sanctuaries, and here they are often interpreted a cheap or "poor" votives rather than items specially associated with children; again however the size might be a by-product of ritual process rather than an indicator of economy (see further PEMBERTON, 2020).

This illustrates that analysis of the context is very important, that we should be wary of limiting ourselves to the "obvious" explanation, and that artefacts can be generic in nature but acquire highly varied meanings according to their specific deployment. Here too it is important to remember the "biography" of an object, that an artefact may have had varied uses throughout its lifetime, including as a toy (CRAWFORD, 2009). So, for example, a miniature vase might have been purchased with a view to a sanctuary dedication, played with by a child while it was in the household, and ultimately used as a grave offering for that child - or indeed for the adult who purchased it in the first place.

A similarly varied and mutable set of uses and meanings might apply to dolls (usually female, and often with articulated joints for movement), known primarily from terracotta examples although no doubt many more existed in perishable materials (e.g wood, cloth). Again, their function does not seem to have been restricted to that of a 
child's toy which combined play with learning nurturing skills. Those that have been found in sanctuaries may well have been dedicated as part of coming-of-age rituals, but it is also possible that they were used as offerings for other purposes, including as apotropaic symbols or (especially in the case of "truncated" dolls lacking lower legs) votive offerings to healing gods such as Askleipios for a healthy female body (REILLY, 1997; MERKER, 2000, p. 48-50). In graves, and especially child graves, dolls may well represent cherished possessions of a child, but may carry other meanings also, such as the idealisation of the Athenian female life course proposed for a late $5^{\text {th }}$ century tomb group in which a doll appears amongst other miniature objects, including an epinetron (PILZ, 2011, p. 22-3). The use of dolls (kolossoi or "voodoo dolls") in sorcery and cursing is also known from ancient Greece, although such identification usually depends on sinister details such as deliberately distorted features, bound limbs, and sometimes even an inscription naming the intended sufferer (FARAONE, 1991). As toys, one wonders if dolls might also have had a role similar to that proposed for Roman dolls, especially with the production of naked dolls (i.e. requiring dressing by a child, mainly dating from the late $5^{\text {th }}$ century: NEILS; OAKLEY, 2003, p. 267), that of engaging girls with ideas of (elite) adult femininity through dress and personal adornment, as well as motherhood and nurture; imaginative play might also have challenged feminine stereotypes in unintended ways (DOLANSKY, 2012).

Fortunately, we do also have a number of vases and figurines which depict children playing. Here the most extensive body of evidence is provided by choes, small wine jugs used for the festival of the Anthesteria in honour of Dionysos, which often depict scenes of children at play as well as other childish activities such as crawling; they are also found in children's graves, perhaps in recognition of the inability to participate in the festival which interestingly also focused on the spirits of the dead as well as the new wine. One such vase depicts an extraordinarily realistic scene of three boys playing knucklebones - their poses and gestures are as familiar to a modern audience as to the ancient (NEILS; OAKLEY, 2003, cat. 86) and as today such games must have been part of the development of manual and social skills, and no doubt also fostered the competitive spirit for which the Greeks are renowned.

So this has been a rather lengthy way of saying that yes, I do think that the toys used by Greek children were intended for paideia, but we need to be aware of the complexities in interpretation of "toys". And even so, we can't ever fully reconstruct the role of play in paideia, given that so much play involves little or nothing in the way of material accessories but much in terms of children's imaginations, and many playthings (one could also add pets) will remain invisible to us through their unrecognisable nature even where they have survived. In this regard we also need to be more open to the 
potential interpretation of an object as a toy or plaything, given the high proportion of children in ancient populations and our tendency to classify an artefact as a "toy" only if appears to be manifestly so to our modern eyes, and/or is found in close association with a child - neither of those criteria will necessarily apply in the archaeological record, but there might be other factors to consider which might help us "see" the activities of a child - I'll discuss this point in more detail in response to the last question.

3. Mortuary images are essential to understand the social experience of death in Mediterranean societies. As we have seen, care for the cult of the dead is revealed in textual and material narratives, such as, for example, epics, epitaphs, reliefs, among others. As we have argued, death is correlated with emotional relationships. Usually, the material and textual traces suggest images about the public expression of pain and the insertion of more particular and emotional dimensions in the way they remembered the dead. We understand that emotions - pain, affection, loss, sadness, anger, contempt, love, among others - are socially elaborated constructions. Understanding them, then, "how they are experienced, expressed and interpreted" (ROSENWEIN, 2011, p. 18. See also: LE BRETON, 2013), to insert them, especially in a time and space, being, therefore, historical elaborations. Therefore, to research them in the mortuary space, to consider them as instruments of sociability. They support and reinforce cultural systems, thus indicating different stages of death rituals. In this sense, when referring to the interdisciplinary nature of emotion studies, could you enlighten us about its applicability to research on children in antiquity? In the sacred environment of death, is it possible to understand the affective dimension of parents facing the death of their children in Greek societies?

R: I think it is possible to gain some sense of the emotional impact on parents of the death of a child in antiquity, but we also need to bear in mind that reactions could be complex, varied, and not necessarily the same as those of other cultures, including our own. This is where recent studies in the history of emotions are very useful - they remind us that emotions are not simply visceral, universal phenomena, but can be shaped by circumstances and cultural practices. For the Greek world one of our problems is the relative lack of textual evidence which expresses those emotions, but that does not mean they did not exist. The use of more abundant evidence from other ancient societies (ancient Rome is an obvious example) or ethnographic parallels from modern societies help provide a sense of both the potentials and the pitfalls of such an investigation.

In the second half of the $20^{\text {th }}$ century, the idea that high child mortality rates in the past meant that parents avoided deep emotional connection with a young child 
as a form of self-protection, since it represented a high risk personal investment, was promulgated in a number of works investigating the history of family life. However these ideas were not universally accepted at the time (both for antiquity and other periods: see especially GOLDEN, 1988, with references), and I think most scholars today are also wary of such assertions while at the same time acknowledging that in antiquity some children could be unwanted, rejected and abandoned as much as others were loved and cherished. Anthropological evidence from high mortality populations indicates that greater likelihood of childhood death does not necessarily result in lesser emotional and practical commitment (GOLDEN, 1988). It is the case that some ancient texts certainly give us the impression that parents shielded themselves from emotional impact, especially in the case of the very young - Cicero for example famously commented that those who complained about untimely deaths also felt that the death of young child should be borne calmly, and the death of an infant in a cradle did not even warrant a lament (Tusculan Disputations 1, 39). But at the same time he also noted that, in the case of the latter, nature had snatched away her gift even more cruelly, and the evidence of other texts (especially epitaphs: for some Roman examples, see CARROLL, 2018, p. 212-13; for Greek, GOLDEN, 1988) provides a counterweight to such allegations. And, as Maureen Carroll (2018, p. 3-4) has pointed out for ancient Rome, often relevant texts were produced by elite men with an interest in promoting self-control in the face of adversity - so it would be hazardous to extrapolate this sort of evidence to the wider population, and consideration of the context and agenda of such texts is essential. That might include the fact that ancient writers felt called upon to raise the issue at all - possibly both an indication that such views were far from universal and an attempt to help parents deal with grief.

For the Greek world, imagery sometimes provides rare glimpses into the sorts of emotional responses parents made, such as the poignant scenes on two Athenian white ground lekythoi of the later $5^{\text {th }}$ century: one (NEILS; OAKELY, 2003, cat. 115) shows Charon waiting patiently in his boat for a small boy standing on rock, in order to ferry him across the river Styx to the Underworld; the boy has a roller (a toy noted above) in one hand and turns with the other outstretched towards his mother, who looks sorrowfully down at him. The other (NEILS; OAKLEY, 2003, p. 174, fig. 14) shows a small boy already in Charon's boat, extending one arm to his parents on the shore who likewise gesture towards him. In this case the poignancy is amplified by Charon's pose: he stands with his hand on his hip, as if both bored and impatient to be off - a comment perhaps on the frequency and repetition of this specific task for Charon as conveyor of the dead?

The archaeological evidence of children's graves is also important to consider here. Another of those elite men, Plato, has Socrates dismiss the ultimate fate of infants who died 
at birth or soon after as not worthy of mention in his account of the Myth of Er (Republic 10.615c); this sort of statement, combined with the varying representation of children in formal cemeteries, the simple and ostensibly perfunctory nature of many of the burials that are found, and the contentious issues of infanticide and exposure, has contributed to the idea that parental sentiment was limited in the ancient Greek world as well the Roman (e.g. KURTZ; BOARDMAN, 1971, p. 331; GARLAND, 1985, p. 80). Yet these factors do not in fact demand a cultural environment in which parents were conditioned to limit their emotional investment in their offspring; rather, they are better seen as responses to prevailing circumstances and indicators of wider cultural attitudes and priorities.

It is very important, I think, to be wary of too close a correlation between levels of grief and mourning on the one hand and method of disposal on the other. Rates of child burials fluctuate very considerably over time and place throughout the Greek world, but (as discussed in more detail in question 5) a range of factors may lie behind that, including the socio-political, and there are a number of explanations for unretrieved child burials other than uncaring and informal disposal. A lack of resources may prevent elaboration of child's burial, or that elaboration may have taken perishable form; by contrast some child burials are extremely wealthy, and while that could well represent an outpouring of parental grief, as suggested below it might also have been a vehicle for the display of family wealth and status. Poverty or illegitimacy might have resulted in the exposure of a child, but that does not preclude an enormous sense of loss and it may well have been accompanied by the hope that the child would be found and reared, hopefully in better circumstances (although not always - the origins of the famous Corinthian prostitute Neaira are unknown, but given that we first hear of her as a child receiving training in a brothel (Demosthenes 49.18), her acquisition via exposure is a distinct possibility).

Such evidence as we have indicates that parental grief in Greek antiquity could well have had much in common in depth and nature with that experienced by parents in the modern world. My suspicion, however - and this is perhaps what our more coldhearted sources hint at, although there is no way of confirming it - is that one respect in which ancient reactions differed from those of the modern developed world is in terms of what could crudely be described as the "shock" factor of a child's death. In antiquity the risk of infant (0-1yr) death was very high, with many estimates suggesting an IMR (infant mortality rate) of 300 per 1000 live births per annum, a stark contrast to the rate of less than 10 per 1000 per annum for the modern developed world; death in subsequent early years may have meant that up to $50 \%$ of children died by the age of 10 . For babies in particular, the likelihood of death was very real; and for a mother, the death of one or more children over her child-bearing years may have been as much an expectation 
as a fear, not to mention the risks to her own life. For many of us today, the death of a child is an unexpected tragedy, and usually a distant one. In classical antiquity - and indeed for other societies right up to the $20^{\text {th }}$ century AD when child mortality was finally reduced through medical advances - there can have been very few individuals who had not directly experienced the loss of a child, whether as a parent, sibling, or other relative. Some sense of inevitability and resignation might thus have accompanied the grieving process, a nuance which would be lacking today in many societies.

4. When considering the Roman Mediterranean, the tomb itself became a memorial. Horace (65-8 B.C.), in one of his Odes, highlighted the tomb constructions to emphasize his permanence among the living, as his reputation would come from his monument of words, his poetry and not from the stone monuments (Horace, Odes 3, 30). This statement leads us to suppose that, unlike poetry, his contemporaries appreciated the funerary monuments, making evident, this time, the attitudes and aspirations of Roman citizens and non-citizens, therefore, in paraphrase to Maureen Carroll (2006, p. 04), the very location of the tombs implied visibility. They became social models, because, in fact, the tombs represented a visual cross-section not of all the inhabitants, but of a differentiated collective of individuals and groups, which re-signified the Roman social values. In this sense, if we think about your area of specialization, Greek societies in the regions of Italy and Sicily, we ask: what would be the images and social positions of children in funerary buildings?

R: Unfortunately, there is not a lot of evidence in terms of images of children on funerary monuments for the Greek world - certainly nothing like, say, the range of Roman sarcophagi from the beginning of the $2^{\text {nd }}$ century AD onwards which show scenes of children and childhood. The best evidence for structures, images and epitaphs commemorating children comes from Athens, but even there it relates mainly to the classical period - there is very little for the earlier archaic period. In general, these monuments, by their very nature, relate to children and families that were relatively wealthy, and in all likelihood with social aspirations if they did not already have recognized elite status. Even so, it is interesting that there is greater visibility of certain groups in funerary imagery - for classical Athens one could add women to the list as well as children - at certain periods and in certain places. Representation of the dead through images, even for elites, is far from being a given in any society.

Elsewhere in the ancient Greek world we have even less evidence for children via funerary structures. For Greek states in archaic and classical Sicily and Italy, this general scarcity should be placed in the context of the overall dearth of evidence for grave markers 
of any sort for all ages and social groups. Yet it seems to me to be fairly clear that burials must have been marked in some way, as indicated by the lack of "collisions" between earlier and later graves (which were very often cut into bedrock), grave plots that probably represent family groups over a generation or more (and very often include child burials), and multiple burials where the interments were not necessarily exactly contemporaneous (again including children) - precise grave locations must have been obvious. But that does not necessarily mean a non-perishable, ornamented or otherwise informative structure. There were certainly some of those - for example, the "hypogeic cella", a rectangular stone-built chamber found as an elite burial type especially at Megara Hyblaea, is likely to have been partially above ground. Other "monuments" could have been, for example, earth tumuli, large vases or wooden markers, none of which would necessarily survive. It is also possible I think - and the levels of wheel ruts in internal cemetery roads also suggest this - that there was little or no topsoil and the stone slabs or lids which very often sealed fossa (trench) and sarcophagus graves were exposed rather than buried, and formed markers in that sense.

That said, there is some evidence for sculptured stone tomb monuments. Most of these relate, or are likely to have related, to elite adult burials - such as the fragments of a stone sphinx from the Fusco Necropolis in Syracuse (comparable to archaic sphinx markers from Athens and Corinth), or the kouros from the South Necropolis at Megara Hyblaea, another type of monument known elsewhere in the archaic Greek world, and in this case with (for Sicily) an unusually detailed inscription telling us that the kouros belonged to Sombrotidas, son of Mandrokles, a doctor (inscriptions are rare in general, and most do not go beyond a formulaic "I am the sema of..."). However, one of the most distinctive grave markers from Sicily (and I would say from anywhere in the archaic Greek world) is the famous kourotrophos statue from the North Necropolis at Megara Hyblaea (GENTILI, 1954). This extraordinary piece was sculpted from local limestone and depicts a seated, curvaceous female enclosing two nursing infants in the protective curve of her arms and mantle. Twins are relatively rare - most kourotrophos figures generally carry one child - and the fact that they are suckling is unusual in Greek art. In fact, in many respects the sculpture finds better parallels in the indigenous art of Sicily and Italy, where images of nursing mothers are more common (BONFANTE, 1997), and as such it might reflect interactions with local populations, including intermarriage and procreation. However, it still remains a highly unusual piece in terms of its scale: the indigenous populations of Sicily do not appear to have had a tradition of monumental sculpture in stone, and in the archaic Greek world images of infants and children tend to be confined to smaller scale works (e.g. terracotta figurines) and are infrequent on large scale funerary monuments. 
Whether or not the kourotrophos actually marked the grave of a child or children is another matter. The North Necropolis bears the hallmarks of a rather exclusive, elite cemetery - in comparison to Megara Hyblaea's other two huge archaic cemeteries, the North Necropolis appears to relate to a small and elite social group of the second half of the $6^{\text {th }}$ century BC. Most of the graves were of the monumental hypogeic cella type noted above, and the kourotrophos statue seems to have adorned one of these (probably Tomb I). Unfortunately, there is no good skeletal evidence available, but it seems most likely that such a grave belonged to one or more adults; it is though possible that a child (or children) was also buried in the grave, especially given the relative frequency of multiple burial at Megara Hyblaea and the low rate of retrieved discrete child burials for this period at the site. Although there have been various interpretations of the sculpture - for example as a personification of Night nursing Sleep and Death (HOLLOWAY, 1991, p. 82-3) - the sculpture may be best seen simply as a projection of female nurturing and motherhood. It is particularly interesting given that it is otherwise relatively difficult to "see" children in Sicilian cemeteries of this period, and especially very young children. For the North Necropolis, the best evidence for an actual burial is so far Tomb $L$, a small stone-lined fossa grave which, judging by its internal length of just over a metre, must have been for a child. But - setting aside the issue of numbers of retrievable child burials- the lack of monuments dedicated to children seems to be as much about general attitudes towards commemorating the dead in archaic and classical Greek Sicily and Italy as it does about attitudes to children, and the same may well be true for many other areas of the Greek world, with Athens in the classical period being a conspicuous exception

5. As noted in ancient documentary sources, the infant mortality rate was significant. Numerous material testimonies are seen, such as amphoras, sarcophagi, urns, which contained the remains of children, including also a considerable number of burials of babies. As Maureen Carroll (2018, p. 180) maintains, when compared to the testimonies of the Roman period, there is no greater investment in children's clothing in the Greek context. In this sense, we asked the teacher for an explanation of premature death and its burial rituals in Greek societies.

R: Maureen Carroll's comments were made in the specific context of the site of Marseille in France, where there is good continuity of evidence from the Greek period to Roman and some subtle distinctions between Greek and Roman practices. This is unsurprising - the manner in which children were treated does fluctuate over time even within more consistent cultural milieux. However, in general I do not think we can clearly distinguish 
the Greeks and Romans on the basis of how they treated the very young at death in terms of expense and effort, and this lack of distinction is due a wide range of methods and approaches. In both cultures burials of infants could vary considerably over time and place in terms of broader cultural practices, as well as more local variations that might be due to socio-economic factors.

One of those variations in cultural practice involves the proportion of deceased children accorded formal burial (or at least a burial that is archaeologically retrievable today) in a designated cemetery, as opposed to disposal elsewhere, informal or not. Estimates vary, but as noted above in general an IMR (infant mortality rate) of about $30 \%$ is likely for antiquity, with perhaps around $50 \%$ of children dying by age 10 . Given that, we should expect to see significant numbers of children in ancient Greek cemetery populations - and sometimes we do. But very often we do not: Athenian burials, for example, display clear shifts in rates of child burial from the Late Geometic period onwards which may be linked to socio-political developments in Athenian society (MORRIS, 1987). In my own work I have noticed fluctuations in numbers of retrieved child burials in archaic Greek Sicily, particularly in relation to enchytrismos (storage vessel) burial, a method used primarily for the disposal of young children and, it appears, largely discarded during the $6^{\text {th }}$ century but not obviously replaced with anything else. Our problem thus becomes not only how to explain these shifts in practice, which must surely be related to the wider social priorities of the adult world, but also to identify how those children were disposed of, and where - since radical improvements in pediatric care and child health will never be the answer for antiquity (see further SHEPHERD, 2018).

Sometimes this apparent dearth of children in main city cemeteries is explicable in terms of the geography of burial. There is evidence throughout the Greek world of childspecific burial areas, whether part of a larger cemeteries (as at Athens, in the Kerameikos: HOUBY-NIELSEN, 1996) or separate child burial grounds. An extraordinary child cemetery is currently under investigation at Kylindra on the island of Astypalaia, where (thus far) well in excess of 3000 burials of children ranging in date between the Late Geometric and Roman eras have been revealed, with most belonging the archaic and classical periods. With only a few exceptions, these are enchytrismos burials of children under two years old, including numerous newborns (HILLSON, 2009). The cemetery thus reflects the high infant mortality rate of ancient Greece, and enchytrismos was a standard form of disposal for the very young throughout the Greek world; however, what makes this cemetery so unusual is its very low and narrow age band, and its sheer size - in Greece even cemeteries representing the full age range of the population are not often on this 
scale. It is a fascinating case of a burial ground reserved for precisely the group that is so often missing from the burial record of ancient Greece, namely the very young.

In other periods and places, very young children might have had a different sort of destination at death. For example, analysis of the contents of the extraordinary "bone well" in the Athenian Agora has provided intriguing insights into Hellenistic Athenian practices. The well, located in a secluded corner, was found to contain approximately 460 infant burials as well as an eight-year old child, an adult male, faunal remains (especially dogs) and rubbish. Although its use to dispose of unwanted and/or illegitimate children through infanticide is a possibility (and birth defects identified such as cleft palate may have contributed to this), the skeletal analysis indicates that in many cases death resulted from common natural causes such as premature birth and neonatal meningitis; the presence of large ceramic vessels which might have been associated with the birthing process and which were also used in normal cemetery contexts as receptacles for infant burials is also significant. In other words, the well might represent a known and socially condoned destination for the very young dead, including still-borns and infants who died shortly after birth (LISTON; ROTROFF; SNYDER, 2018). If this seems a callous approach to us today (cf. question 3 above) then it is worth remembering that in many modern Western societies funerals and related procedures for foetuses and still-borns are relatively recent phenomena adopted in recognition of their role in the grieving process and acknowledgment of the identity of the child as a human being (GOWLAND, 2018, p. 109-10); in past decades small corpses were often disposed of by hospitals as clinical waste, and sometime still are.

As well as location, methods and receptacles can vary significantly for children. Inhumation is most common; cremation does occur, but is relatively infrequent, possibly for cultural reasons and/or the practical difficulties of cremating smaller bodies. As noted above, enchytrismos was a very common method, and is sometimes assumed to be a "poor" form of burial, especially given the "recycled" nature of the receptacle. There may well be issues of economy involved, especially in cemeteries where we also see "wealthy" containers, such as small monolithic sarcophagi which may reflect greater disposable parental wealth. However, it seems to be also the case that enchytrismos was simply deemed appropriate, and was a normal, socially approved form of disposal - as seems to be the case at Kylindra, where the idea that the Greeks saw the pot as enclosing, protective and symbolic of the womb is revisited with new information on corpse position (HILLSON, 2009, p. 142). Some enchytrismos burials could incorporate quite elaborately decorated pots as opposed to the more common reused transport amphora (for example the $7^{\text {th }}$ century Tombs 216, 394, 445 and 500 in the Fusco Necropolis at Syracuse: ORSI, 1895), 
again indicative that this method was an entrenched cultural norm rather than simply a practical convenience (even if it began as such).

Some child burials, so far from being poor, cursory or informal in nature, could in fact be very elaborate and/or wealthy in their contexts, often rivalling their adult counterparts. Here it can be hard to separate the outpouring of parental grief via elaboration of the grave from the use of the funerary arena to display parental wealth - both of course could operate at the same time. Western Greece provides some good examples of conspicuously wealthy child burials, such as Tomb 501 at Megara Hyblaea (West Necropolis: ORSI, 1913), containing three children described as "literally covered in silver" (my translation) and viewed by the excavator Paolo Orsi as the richest of the thousand-odd graves he had opened at the site. An interesting feature of many of these "wealthy" child burials is not just their more expensive receptacles and grave goods, but also the fact that many of them appear more "adult" in both method and contents, and in that regard seem to breach distinctions between children and adults at death at their particular sites. For example, one of the earliest burials in the Fusco Necropolis in Syracuse was T. 216 (ORSI, 1895), a very young child buried in a large bronze vessel. Metal vessels are always rare in Greek cemeteries, but secondary cremations of adults contained in bronze vessels are known across the Greek world from the Geometric to Hellenistic periods, and are generally viewed as "heroic" in nature due to their apparent allusions to Homeric burials - what was it about this child that prompted an extraordinary burial akin to that reserved for just a few adults at best? At Pithekoussai in the Late Geometric period a boy of perhaps 12 was not buried in a fossa grave, as was normal for individuals of his age, but was cremated and his ashes collected under a stone tumulus, a method and arrangement normally reserved for affluent and older members of Pithekoussan society (BUCHNER; RIDGWAY, 1993, p. 212-23). Further, no fewer than 27 vases were smashed and burnt on his funeral pyre (including the famous "Nestor Cup" with its inscription referencing not only Homer but the adult male social context of the symposion) and he was buried with a silver serpentine fibula, an ornament which may have signified adult male status at Pithekoussai. Some children - possibly heirs, whose deaths interrupted blood lines and inheritance - seem to have acquired "adult" status at death.

6. As we explore questions about the organization of Greek oikos and their social and spatial relationships, we find discussions about relationships, behaviors and domestic activities. It is known, therefore, that oikos at the classical time included the couple, children, grandparents, aunts, among others; that is, it represented a complex entity that accommodated different nuclear or extended families. The residences included male activities, storage, processing, 
food preparation and consumption, textile production and children's education (CF. TRÜMPER, 2011). In view of these notes, we would like the teacher to talk to us about the daily life and education of children within oikos.

R: This is a question which really highlights the gaps in our knowledge and the difficulties of the evidence available to us. We envisage the oikos as a primary space for children, yet "seeing" them in that space is extremely difficult. As Trümper's (2011, with references) work indicates, there has been considerable scholarly investigation of the practical arrangements and social relationships of the Greek household, especially on the basis of the archaeological evidence since the textual sources are limited in both number and utility. Much of this work has focused on gender relationships, especially the nature and extent of segregation of females within the house, with some investigation of ethnic and cultural identities also. Other social groups and relationships have proved even more problematic. For example, some (maybe many - even this is debated) households would have had one or more slaves, but identification of "slave quarters" generally eludes us apart from some tentative suggestions (e.g. TRÜMPER, 2011, p. 43; 50) and it is entirely possible that slaves had no "personal" space in the oikos beyond, say, a corner for sleeping in a room with other primary function(s). Age groups (children, and also the elderly) represent another elusive category, compounded by our difficulties in defining the material culture of ancient Greek childhood, which is often more readily identifiable in other contexts such as graves. An important factor here is also the very distinct possibility that rooms in ancient households were less function-specific than in modern households, but rather were multipurpose spaces; even a room like the andron, probably the most readily identifiable space (thanks to features such as more elaborate decoration and off-centre doorways to allow for dining couches) may well have been used by other members of the household outside symposium occasions - including children.

This "invisibility" of children in domestic space is - rather frustratingly - not really counteracted by vase painting which appear to show children in that space. A problem here is that - as so often - our best visual evidence from vases comes from classical Athens, but we know relatively little about domestic architecture in Athens and should be cautious about links with the evidence of sites that are better understood but also geographically (and sometimes chronologically) distant, such as from $4^{\text {th }}$ century Olynthos with its far more extensive architectural evidence. We have some charming vase images of children in domestic settings - one of my favorites is the tondo image of a kylix attributed to the Sotades Painter which depicts a child in a high-chair reaching out to a seated woman, probably the mother given her pose and attire (c. 460 BC, NEILS; OAKLEY, 2003, cat. 42). 
The high-chair probably also functioned as a potty and in fact a ceramic example was found in the Athenian agora (P18010) - a very rare example of a piece of furniture made expressly for children. Yet, apart from the fact that this is obviously a domestic scene, it gives little away in terms of the physical oikos. In many ways this is typical of Athenian vase painting, where human action is used primarily to indicate setting, rather than scenery as such: at most we get children in "boudoir" scenes which also show women and basic domestic equipment (chairs, stools, baskets etc) or children on their own, often playing with toys (NEVETT, 1999, p. 43-45). For the latter the setting is unspecified and the nature of the activity does not always help - it could be in a room, the courtyard of a house, or outside in the street. Tellingly, most of the children depicted are shown as males - an indicator of the importance of a male heir for the oikos.

Daily life and education for children within the oikos must have depended very much on both gender and social status. For boys, education often occurred in the home, with a tutor or paidogogos who was usually a slave, but there is also evidence of schools, some of which may in fact have operated within private oikoi. But at the same time boys, especially those of elite or at least well-off families, must have spent significant amounts of time outside their own oikos for athletics and also military training, considered essential features of education; music was also very important, and lessons could have taken place in the oikos or at music schools, which seem to have existed by the $5^{\text {th }}$ century in Athens at least (cf. Aristophanes, Clouds, 961-83). Likewise reading and writing were taught privately in the home, but there is also evidence of quite large schools: in the $5^{\text {th }}$ century both Herodotus and Thucydides described mass tragedies involving boys at school, on Chios when a roof collapsed on 120 boys learning their letters and all but one perished (Herodotus, 6, 27), and in Boeotia when Thracian mercenaries sacked a town and killed boys at a large school (Thucydides, 7, 29, 4-5). Vase paintings sometimes illustrate school scenes (e.g. NEILS; OAKLEY, 2003, cat. 44). For well-off boys, when they were older, the symposium could well have provided additional educational opportunities within the oikos when it was opened to adult outsiders (MORGAN, 2011). For other boys, from poorer families, such education was not necessarily available to them, and their "education" took the form of learning skills necessary for economic survival, often involving an active contribution to family welfare. Again this would often take place outside the oikos - such as tending to the family sheep while wealthier boys were at school (Lysias, 20, 11-12), or workshop tasks, as in the case of the boy turning a potter's wheel on a $5^{\text {th }}$ century calyxkrater (Museo Regionale della Ceramica 961, Caltagirone, BAPD 4355). Many children must have worked with parents in the same profession, as well as other adults. 
Education for girls focused on their future role of working in and running a household, though perhaps with more stress on the latter for wealthier girls who would need to manage slaves, and on the former for girls who would have to do more of the actual work themselves. This would have taken place within the oikos, and by its very nature leaves no material trace, although occasionally we see charming vignettes of this form of education, such as the 5 th century Boeotian figurine of a girl and adult woman at a cooking pot - presumably a cooking lesson is in progress (NEILS; OAKLEY, 2003, cat. 61). As this scene indicates, this education for girls in the work (including the important skills of wool-working and weaving) and management of the oikos must have come primarily from older women in the household - as has been pointed out, the broader implication of Xenophon's Oikonomikos - where an elite Athenian male teaches his ignorant young wife how to run a house - that household management was taught to sons who then imparted it to females seems highly unlikely (MORGAN, 2011, p. 518). A problematic area is the extent to which girls were taught literacy: it is clear that at least some ancient Greek women could read and write, and while that group probably came mainly from the wealthy elite, there was also the risk that education could threaten the reputation of a respectable woman (see further MORGAN, 2011, p. 518-9). Whatever its extent, however, it seems most likely to have taken place within the oikos: the evidence for girls attending schools is limited and mainly of the Hellenistic period, although an intriguing tondo in a $5^{\text {th }}$ century kylix could be interpreted as depicting a girl (carrying a writing case) being pulled along to school by another girl (NEILS; OAKLEY, 2003, cat. 46).

The daily life and "education" of some children was of the grimmest kind - as child slaves. Neaira, the $4^{\text {th }}$ century Corinthian prostitute mentioned above, is described as one of seven girls acquired by one Nikarete as small children to be trained as sex workers from a young age (Demosthenes, 49, 18-19); a 5th century lekythos attributed to the Phiale Painter shows one feature of this sort of education, a dancing lesson (NEILS; OAKLEY, 2003, cat. 58). In this case the social position of the girl is made clear not only through her activity but also her nudity; elsewhere slaves (both child and adult) are harder to identify in Greek art because slave dress did not necessarily differ significantly from that of free citizens. A female child slave appears to be shown on a $5^{\text {th }}$ century Attic kylix NEILS; OAKLEY, 2003, cat. 63): the diminutive figure, burdened by a sack over her back, a full wineskin on her head, and a pot in her right hand, struggles along behind an adult woman (the mistress?) who gulps from a large skyphos as they head towards a storeroom with symposium equipment, depicted on the other side. Whether or not this is the storeroom of a respectable oikos is less clear: women in general were accused of an uncontrollable desire for drink, but given the loose dress and double chin of the woman this vase might 
be a closer illustration of the daily life of children like Neaira under her mistress Nikarete. Child slaves, and no doubt other poorer children, often had to do manual work that was physically demanding, or otherwise unpleasant - as for example the boy, encumbered with stick and basket, who holds a pot for a drunken reveler to urinate in (NEILS; OAKLEY, 2003, cat. 66).

Some of the work which formed both the education and daily life of these less affluent children is now being further investigated through the application of interesting new methods and techniques in examining artefacts - I note some of these in the last question.

7. If we consider tragic narratives, we will see, above all, the transgression of kinship values (Cf. BOEDEKER, 2008). In Euripides' Heracles, for example, the hero, driven by madness, murders his wife and his own sons (e.g. v. 1365-1385). Following this argument, what would be the social, political and religious roles of Greek children in the tragic and philosophical spatialities (e.g. Plato, Republic 4 431c; Aristotle, Politics 1, 5, 8-1 1260a)? We would also like to know if it is possible to establish a connection between children's images in ceramics from the Classical period and textual discursive devices, thus realizing similarities and differences in the way childhood is portrayed?

R: This is a complex question which probably needs much more space than is available here, and also a more detailed knowledge of the literary and philosophical sources that I (as a classical archaeologist) would claim to have. But in putting your two questions together - the images of children in literary and philosophical texts on the one hand and on painted vases (and figurines?) on the other - it strikes me that in using these sources we encounter many of the same sorts of issues that are found in using these sources to reconstruct the lives of women and also slaves in the ancient Greek world.

First and foremost is the relative lack of evidence, in comparison for that for (elite) males; another is the nature of the evidence, given that it was those same elite males who produced the texts, and the painted pottery - although it can provide a very different range of images - was we think also produced mainly by adult males, although of lower status. Much has to be gleaned from passing, often oblique and ambiguous references in texts rather than extended discussion (including disentangling the reality from the hyperbole in one of our most important sources, comedy) and our images of children on pottery, especially on choes, have a chronological bias of the later $5^{\text {th }}$ to earlier $4^{\text {th }}$ centuries. And as is so often the case in any sort of investigation of ancient Greek society - much of this 
evidence comes from classical Athens and so we need to exercise caution in extrapolating interpretations of that evidence to other times and other parts of the Greek world.

The role of the child in tragedy, philosophy and indeed other texts can be that of a narrative device and vehicle for other main themes, and so the conceptions of children and childhood in those texts must be examined carefully in that context. In Greek myth and tragedy, child exposure is a well-established motif (in the stories of Oedipus, Paris and lon for example) which at the very least is a device to progress the narrative, often one revolving around the retention/removal of adult male power to which the early life experiences of the child add further piquancy. Our problem here, as elsewhere, is how far this narrative motif can be applied to reality - and in the case of exposure (and the related issue of infanticide), the emphasis of literature on the unusual needs to be remembered. Something similar applies to Socrates' use of the motif of examining an idea in the manner that one would examine a child - to see if it is sound and should be retained/ reared or rejected/exposed (Plato, Theaetetus 151c; 160e-161a). Such child-related actions may have been familiar enough to an ancient audience to make them useful devices in contexts of wider and different themes and debates, but that does not necessarily mean they were also common practices in that same society. The dysfunctional families of the gods should also be viewed cautiously in terms of their relationship with reality - for example, Hera hurling her son Hephaistos out of Olympos in disgust at his deformed feet may also reflect some recognizable reality for the ancient Greeks, but it is not clear how far we should extend that attitude. The best parallel may come from ancient Sparta, where babies were reportedly formally examined and those with physical defects consigned to the chasm of the Apothetae (Plutarch, Lycourgos, 16, 1-2), but Sparta in general appears to have had very different cultural practices from the rest of Greece, and our knowledge of those could well be coloured by misunderstanding or exaggeration on the part of our non-Spartan (and often Athenian) sources.

Elsewhere, children are used as devices to promote wider themes related to adult behavior, priorities and anxieties. The actions of the young Iphigenia in Euripides' Iphigenia in Aulis serve to place her father - and indeed most of the other adults in the play, including the entire Greek army - in an ignoble light, and may also reflect particular fears about the deaths of children in a society where keeping a child alive was a challenge in itself (PRATT, 2013, p. 235). In Herakles, the hero kills the very children he has in fact come to save, one of the many dichotomies of the play and made more poignant by Herakles' assertion which may actually tell us more about the ancient Greeks' attitudes to their children: "That's what the whole of mankind is like: rich or poor, they all love their children. Wealth and poverty might be two different things but the love of children is the 
same throughout the race of mortals" (Euripides, Herakles, 633-36, trans. G. Theodoridis). Medea kills her children in revenge for Jason abandoning her for another woman; while such family tragedies may have occurred in ancient Greece - just as such appalling cases of domestic violence appear all too frequently in news headlines today - neither Medea nor her actions provide us with much help in reconstructing the banalities of daily life and the raising of children in the average Greek oikos, but rather they belong to the racier world of myth and literature where general truths may be encapsulated by atypical events. Thus we might again extract some contemporary realities, such as the plight of women in general and young new brides in particular (Euripides, Medea 231; 238-40), all the more interesting because they come from a male playwright. Even in history writing references to children might be effectively deployed to highlight features of the adult world rather than childhood per se: the reports of mass killings of school boys by Herodotus and Thucydides cited above provide important evidence in passing of large schools and are indicative of the value of children and the tragedy of their untimely deaths for the ancient Greeks, but also appear in the context of describing the predicaments and nature of ("other") adults, in both cases during war: for Chios, an unmistakable god-sent sign to the Chians of impending doom, and for the Boeotian boys a demonstration of the particularly bloodthirsty nature of the Thracian barbarians.

In terms of connecting the images with texts we face similar problems in extracting what might reflect common attitudes and behaviour as opposed to illustration of the atypical or the manipulation of the image to send messages other than of the realities of childhood. Some are relatively straightforward: for example, scenes of the young Achilles being handed over to the centaur Chiron to be educated may reflect the relinquishment of children for training and education (NEILS; OAKLEY, 2003, cat. 14); equally, scenes of Herakles murdering his music teacher (e.g. BAPD 205174, attributed to Douris) do not, presumably, illustrate a common event in the education of elite boys but are probably more about demonstrating the precocious nature of the hero, who also strangled serpents in his cradle (PRATT, 2013, p. 239) and might also display a juvenile inability to distinguish right from wrong (cf Aeschines, Against Timarchos, 18). Astyanax being used as weapon by Neoptolemos to batter the old and helpless Priam on a vase scene depicting the fall of Troy (BAPD 206829, attributed to the Altamura Painter) is an interesting departure from the myth where he is thrown from the walls of Troy (including in Euripides' Trojan Women 1120-22); it is thus seems more about highlighting the atrocities of war (with some selfexamination? See also the Ilioupersis scene with Astyanax attributed to the Kleophrades Painter (BAPD 201724), where all the Greeks behave badly) and the destruction of the past 
and future of Troy than it is about the practicalities of sacking a city. At the same time, however, we are reminded that children were very much victims of war also.

At the other end of the spectrum, vase paintings allow us to glimpse images of everyday, familiar childhood activities in more detail than in the limited references of our literary sources - such as the scene of Hermes and a boy playing with a spinning top, where a god joins in on an everyday pastime (NEILS; OAKLEY, 2003, cat. 16) - from learning to crawl and work, to playing and education, and even the use of the potty. In sum, the information we get from literary and philosophical texts is complicated: it probably does not directly reflect the experiences of ancient Greek children, but it nevertheless contains important indications of the range and nature of ancient Greek conceptions not only of childhood but other aspects of the human state as well. The evidence of ceramic imagery elaborates, enlarges and sometimes even challenges this discourse.

8. According to statements by Maureen Carroll (2018, p. 240), archaeological evidence has become the backbone of her book entitled Infancy and Earliest Childhood in the Roman World. For the studious, written sources, when immediately relevant to a child's life and circumstances, were cited constantly, but did not dominate the discussion. Here, we do not intend to produce, as a watershed, the discussion on the merits of textual and material traces; and we do not believe that the researcher wanted to return, nowadays, to the recurring disputes between History and Archeology, especially from the 1980s and 1990s. However, we wanted to end our interview by thanking the teacher for her willingness to participate in this dossier, in the form of an interview, and to invite her, finally, to explain her point of view on the birth and development of children from an archaeological perspective (Cf. CRAWFORD et al, 2018; GOWLAND, 2018, etc.).

R: The archaeology of childhood in the past, and especially in the context of classical antiquity, is a relatively recent area of study. Some works of the earlier $20^{\text {th }}$ century examined categories of "child" objects and activities (e.g. ELDERKIN, 1930 on dolls; KLEIN, 1932), but in general there was little scholarly focus on children and childhood per se, as opposed to passing reference in the context of other studies (vase painting, gravestones etc). That situation started to change in the later $20^{\text {th }}$ century, both for classical antiquity and other areas of archaeology, notably through Grete Lillehammer's seminal paper "A Child is Born: The Child's World in an Archaeological Perspective" (LILLEHAMMER, 1989) which called for the development of means and methods in the study of childhood in the past through archaeology. Around the same time, Mark Golden was making very important contributions to the study of ancient Greek childhood, especially through his 
book Children and Childhood in Classical Athens (GOLDEN, 1990; see also GARLAND,1990), although it focuses on textual evidence rather than imagery or archaeology; but major studies of children in material culture also started emerge for classical antiquity (e.g. HUSKINSON, 1996 on Roman child sarcophagi). That shift in scholarly interest has escalated in the first two decades of the $21^{\text {st }}$ century, when further important studies have appeared which actively engage material culture and indeed also modern public interest, notably through the Hood Museum of Art Coming of Age in Ancient Greece: Images of Childhood from the Classical Past exhibition (NEILS; OAKLEY, 2003) and its associated conference, published as Constructions of Childhood in Ancient Greece and Italy (COHEN; RUTTER, 2007). The area is now burgeoning, with numerous extended studies as well as shorter papers (e.g. BEAUMONT, 2012 on Athenian childhood; CARROLL, 2018 on Roman infancy) and collected works, many of which include studies relevant to the classical world even where antiquity is not the main theme (e.g. EVANS GRUBBS; PARKIN; BELL, 2013; CRAWFORD et al., 2018; BEAUMONT, 2012).

With these studies come new ways of thinking which consider children as present and having agency in the past, exploring new lines of interpretation. For example, a collection of small objects (including miniature pots, spindle whorls, shells, quartz pebbles and a rare figurine) found at the Early Iron Age site of Assiros is difficult to interpret as funerary, accidental or functional in nature; and while some ritual or shamanistic purpose (the usual default explanation for otherwise inexplicable assemblages) cannot be excluded, the excavators have argued that both the collection and its context indicate that it could be a child's cache of treasured items - the sort of assemblage which could readily be paralleled today in children's play (WARDLE; WARDLE, 2007).

Such new interpretative approaches, which seek to consider children as possible agents rather than simply adopting the long-standing default position of seeing only adult actions in the archaeological record, are now also being enhanced through modern studies of childhood cognitive development, ethnographic studies and also the application of scientific techniques. For example, items of $8^{\text {th }}-7^{\text {th }}$ century bronze work and pottery, which have previously been dismissed as hasty, cheap or unskilled, are now being reassessed on the basis of various criteria (such as scale and lack of understanding of motifs) as the outputs of child learners/producers rather than incompetent adults the sort of investigation of essential learning processes in manufacture which is long overdue (LANGDON 2013). Technical details, such as juvenile fingerprints in damp clay, also provide important new lines of enquiry. Research in developmental psychology is also being applied to bodies of evidence such as ancient graffiti, providing more sophisticated identification of children as creators, as opposed to older and unreliable criteria such as 
low placement of graffiti on walls and crude design (e.g. HUNTLEY, 2018 for Pompeii and Herculaneum). Such studies not only illustrate child agency through the image itself, but also the interests and interactions of children and, as fixed physical "objects", also aid us in understanding the use of both public and private space by children. Studies of modern children's play, while they must be used cautiously, nevertheless open up a greater range of interpretations in the study of specific object types, such as for the Roman dolls cited above (DOLANSKY, 2012, p. 278-82).

Advances in the analysis of skeletal material are also proving extremely important. For example, the re-analysis of cremated bone material from the Geometric burial of the "Rich Athenian Lady" revealed the presence of a foetus, as well as the adult woman, probably carried to near full term but not delivered successfully (LISTON; PAPADOPOULOS, 2004); this revelation alters our interpretation of this burial since the loss of a perceived heir may now be an important factor in its ostentation. The identification of the neonatal line, which is formed in tooth enamel and dentine at the point of birth, is now also allowing distinctions to be made between live births and miscarriages or still births, important not only when assessing child mortality rates (the IMR generally refers to live births) but also in understanding ancient attitudes towards unsuccessful pregnancies and labour. In the case of the Athenian Agora "bone well", skeletal analysis revealed the well not only as a repository for normal infant deaths (and not necessarily unwanted babies) as noted above, but also a possible instance of child abuse, again an aspect of ancient childhood which warrants further research and one with particular resonances for modern societies increasingly aware of issues of violence towards children (LISTON; ROTROFF; SNYDER, 2018, p. 32-36, 46).

All in all, the future of childhood in the past looks very exciting.

Thank you very much.

\section{References}

BAPD = Beazley Archive Pottery Database. Disponível em: <https://www.beazley.ox.ac.uk $>$.

\section{Documentary corpus:}

AESCHINES. Speeches. Translated by C. D. Adams. Cambridge: Harvard University Press, 1919.

ARISTOPHANES. Clouds. Edited and translated by Jeffrey Henderson. Cambridge: Harvard University Press, 1998. 
ARISTOTLE. Politics. Translated by H. Rackham. Cambridge: Harvard University Press, 1959.

CICERO. Tusculan Disputations. Translated by J. E. King. Cambridge: Harvard University Press, 1927.

DEMOSTHENES. Orations 41-49: private cases. Translated by A. T. Murray. Cambridge: Harvard University Press, 1939.

EURIPIDES. Cyclops. Alcestis. Medea. Edited and translated by David Kovacs. Cambridge: Harvard University Press, 1994.

EURÍPIDES. Héracles. Tradução de Cristina Rodrigues Franciscato. São Paulo: Palas Athena, 2003.

EURIPIDES. Herakles. Translated by G. Theodoridis. Disponível em: <https://www. poetryintranslation.com/theodoridisgeuripidesherakles.php>. Acessado em: 20 dez. 2020, 2012.

HERODOTUS. The Persian Wars. Translated by A. D. Godley. Cambridge: Harvard University Press, 1922.

HORACE. Odes et Épodes. Traduit par F. Villeneuve. Paris: Les Belles Lettres, 2002.

LYSIAS. Lysias. Translated by W. R. M. Lamb. Cambridge: Harvard University Press, 1930.

PLATO. Theaetetus. Sophist. Translated by Harold North Fowler. Cambridge: Harvard University Press, 1921.

PLATON. La République. Traduit par Émile Chambry. Paris: Belles Lettres, 1949.

PLUTARCH. Lives. Translated by Bernadotte Perrin. Cambridge: Harvard University Press, 1914. 1 v.

SOPHOCLES. Ajax. Translated by A. F. Garvie. Liverpool: Liverpool University Press, 1998.

THUCYDIDES. History of the Peloponnesian War. Translated by C. F. Smith. Cambridge: Harvard University Press, 1919.

\section{General works}

ARIÈS, P. Centuries of childhood: a Social History of family life. London: Penguin, 1962.

BEAUMONT, L. Childhood in Ancient Athens: iconography and Social History. London: Routledge, 2012.

BEAUMONT, L. Children in Antiquity. London/New York: Routledge, 2012.

BOEDEKER, D. Family matters: domestic religion in Classical Greece. In: BODEL, J.; OLYAN, S. M. (ed.). Household and family religion in Antiquity. Oxford: Wiley-Blackwell, 2008, p. 229-247. 
BONFANTE, L. Nursing mothers in classical art. In: KOLOSKI-OSTROW, A. O.; LYONS, C. L. (ed.). Naked Truths: women, sexuality and gender in Classical Art and Archaeology. London/New York: Routledge, 1997, p. 174-96.

BUCHNER, G.; RIDGWAY, D. Pithekoussai I. Monumenti Antichi dei Lincei, serie monografica, V. 4, 1993.

CARROLL, M. Roman funerary commemoration in Western. Oxford: Oxford University Press, 2006.

CARROLL, M. Infancy and earliest childhood in the Roman World. Oxford: Oxford University Press, 2018.

COHEN, A.; RUTTER, J. B. (ed.). Constructions of childhood in Ancient Greece and Italy. Princeton: American School of Classical Studies at Athens, 2007.

CRAWFORD, S. The archaeology of playthings: theorising a 'toy' stage in the biography of objects. Childhood in the Past, n. 2, 2009, p. 55-70.

CRAWFORD, S. et al. The Archaeology of Childhood: the birth and development of a discipline. In: CRAWFORD, S.; HADLEY, D. M.; SHEPHERD, G. (ed.). The Oxford Handbook of the Archaeology of Childhood. Oxford: Oxford University Press, 2018, p. 3-37.

DOLANSKY, F. Playing with gender: girls, dolls, and adult ideals in the roman world. Classical Antiquity, n. 31/2, p. 256-92, 2012.

ELDERKIN, K. Jointed dolls in Antiquity. American Journal of Archaeology, n. 34, p. 455-79, 1930.

EVANS GRUBBS, J.; PARKIN, T.; BELL, R. (ed.). The Oxford handbook of childhood and education in the Classical World. Oxford: Oxford University Press, 2013.

FARAONE, C. Binding and burying the forces of evil: the defensive use of voodoo dolls in Ancient Greece. Classical Antiquity, n. 10/2, p. 207-20, 1991.

GARLAND, R. The Greek way of death. London: Duckworth, 1985.

GARLAND, R. The Greek way of life: from conception to old Age. London: Duckworth, 1990.

GENTILI, G.V. Megara Hyblaea: tombe arcaiche e reperti sporadici nella proprietà della «RASIOM» e tomba arcaica in predio Vinci. Notizie degli Scavi, p. 80-113, 1954.

GOLDEN, M. Did the ancients care when their children died? Greece \& Rome, n. 35/2, p. 153-63, 1988.

GOLDEN, M. Children and childhood in Classical Athens. Baltimore: Johns Hopkins University Press, 1990.

GOWLAND, R. Infants and mothers: linked lives and embodied life courses. In: CRAWFORD, S.; HADLEY, D. M; SHEPHERD, G. (ed.). The Oxford handbook of the Archaeology of Childhood. Oxford: Oxford University Press, 2018, p. 104-122. 
HILLSON, S. The world's largest infant cemetery and its potential for studying growth and development. In: SCHEPARTZ, L. A.; FOX, S. C.; BOURBOU, C (ed.). New directions in the skeletal biology of Greece. Princeton: American School of Classical Studies at Athens, 2009, p. 137-54.

HOLLOWAY, R.R. The Archaeology of Sicily. London: Routledge, 1991.

HOUBY-NIELSEN, S. Women and the formation of the Classical Athenian state: the evidence of the burial customs. Mètis: Anthropologie des Mondes Grecs Ancieéns, n. 11, p. 233-60, 1996.

HUNTLEY, K. V. Children's graffiti in Roman Pompeii and Herculaneum. In: CRAWFORD, S.; HADLEY D. M.; SHEPHERD, G. (ed.). The Oxford handbook of the Archaeology of Childhood. Oxford: Oxford University Press, 2018, p. 376-86.

HUSKINSON, J. Roman children's sarcophagi: their decoration and social significance. Oxford: Clarendon Press, 1996.

KLEIN, A. Child life in Greek Art. New York: Columbia University Press, 1932.

KURTZ, D. C.; BOARDMAN, J. Greek burial customs. London: Thames and Hudson, 1971.

LE BRETON, D. A antropologia da dor. São Paulo: Unifesp, 2013.

LANGDON, S. Children as learners and producers in early Greece. In: EVANS GRUBBS, J.; PARKIN, T.; BELL, R. (ed.). The Oxford handbook of childhood and education in the Classical World. Oxford: Oxford University Press, 2013, p. 172-94.

LILLEHAMMER, G. A child is born: the child's world in an archaeological perspective. Norwegian Archaeological Review, n. 22/2, p. 91-105, 1989.

LISTON, M. A.; PAPADOPOULOS, J. K. The "Rich Athenian Lady" was pregnant: the anthropology of a geometric tomb reconsidered. Princeton: American School of Classical Studies at Athens, 2004, p. 7-38.

LISTON, M. A.; ROTROFF, S.; SNYDER, L. M. The Agora Bone Well. Princeton: American School of Classical Studies at Athens, 2018.

MERKER, G. S. Corinth XVIII Part IV: The Sanctuary of Demeter and Kore. Terracotta Figurines of the Classical, Hellenistic and Roman periods. Princeton: The American School of Classical Studies at Athens, 2000.

MORGAN, T. Ethos. The socialization of children in education and beyond. In: RAWSON, B. (ed.). A Companion to families in the Greek and Roman Worlds. Oxford: WileyBlackwell, 2011, p. 504-20.

MORRIS, I. Burial and ancient society: the rise of the Greek city state. Cambridge: Cambridge University Press, 1987.

NEILS, J.; OAKELY, J. H. (ed.). Coming of age in Ancient Greece: images of childhood from the Classical Past. New Haven: Yale University Press, 2003. 
NEVETT, L.C. House and society in the Ancient Greek World. Cambridge: Cambridge University Press, 1999.

ORSI, P. Siracusa: Gli scavi nella necropoli del Fusco a Siracusa nel giugno novembre e dicembre del 1893. Notizie degli Scavi, p. 109-92, 1895.

ORSI, P. Contributi alla storia della fibula greca. In: SALIN, B (ed.). Opuscula Archaeologica Oscari Montelio Septuagenario dicata. Holms: I. Haeggstroemii, 1913.

PARKIN, T. The demography of infancy and early childhood in the Ancient World. In: EVANS GRUBBS, J.; PARKIN, T.; BELL, R. (ed.). The Oxford handbook of childhood and education in the Classical World. Oxford: Oxford University Press, 2013, p. 40-61.

PEMBERTON, E. Small and miniature vases at ancient Corinth. Princeton: American School of Classical Studies at Athens, 2020, p. 281-338.

PILZ, O. The uses of small things and the semiotics of Greek miniature objects. In: SMITH, A. C.; BERGERON, M. (ed.). The gods of small things. Toulouse: Presses Universitaires du Mirail, 2011, p. 15-30.

PRATT, L. Play, pathos and precocity: the three p's of Greek literary childhood. In: EVANS GRUBBS, J.; PARKIN, T.; BELL, R. (ed.). The Oxford handbook of childhood and education in the Classical World. Oxford: Oxford University Press, 2013, p. 227-45.

ROSENWEIN, B. H. História das emoções: problemas e métodos. São Paulo: Letra e Voz, 2011.

REILLY, J. Naked and limbless. Learning about the feminine body in ancient Athens. In: KOLOSKI-OSTROW, A. O.; LYONS, C. L. (ed.). Naked truths: women, sexuality and gender in Classical Art and Archaeology. London: Routledge, 1997, p. 154-73.

SHEPHERD, G. Where are the children? Locating children in funerary space in the ancient Greek world. In: CRAWFORD, S.; HADLEY D. M.; SHEPHERD, G. (ed.). The Oxford handbook of the Archaeology of Childhood. Oxford: Oxford University Press, 2018, p. 521-38.

TRÜMPER, M. Space and social relationships in the Greek oikos of the Classical and Hellenistic Periods. In: RAWSON, B. (ed.). A companion to families in the Greek and Roman Worlds. Oxford: Wiley-Blackwell, 2011, p. 32-52.

WARDLE, D.; WARDLE, K. A. The child's cache at Assiros Toumba, Macedonia. In: CRAWFORD, S.; SHEPHERD, G. (ed.). Children, childhood and society. Oxford: Archaeopress, 2007, p. 29-44. 